Article

\title{
Investigating the Aluminothermic Process for Producing Ferrotitanium Alloy from Ilmenite Concentrate
}

\author{
Ji-Hyuk Choi ${ }^{1}{ }^{(D}$, Hankwon Chang $^{1}$, Taegong Ryu ${ }^{1}$, Chul-Woo Nam ${ }^{1}{ }^{(D)}$ and Byung-Su Kim ${ }^{1,2, *}$ \\ 1 Mineral Resources Research Division, Korea Institute of Geoscience \& Mineral Resources (KIGAM), \\ Daejeon 34132, Korea; blt_27@kigam.re.kr (J.-H.C.); hkchang@kigam.re.kr (H.C.); tgryu@kigam.re.kr (T.R.); \\ baram@kigam.re.kr (C.-W.N.) \\ 2 Department of Resources Recycling, University of Science and Technology, Daejeon 34113, Korea \\ * Correspondence: bskim@kigam.re.kr; Tel.: +82-42-868-3619
}

Received: 7 October 2020; Accepted: 7 November 2020; Published: 9 November 2020

\begin{abstract}
The aluminothermic process is used for producing ferrotitanium alloy (FeTi) from an ilmenite concentrate. In this study, based on thermodynamic calculations and experiments, we investigated the effects of adding varying amounts of exothermal agent $\left(\mathrm{NaClO}_{3}\right)$, slag-forming agent $(\mathrm{CaO})$, and reducing agent $(\mathrm{Al})$ on the recovery ratio of $\mathrm{Ti}$ in the aluminothermic process. The thermodynamic calculations suggested that the exothermal agent plays a crucial role in producing the FeTi alloy from the ilmenite concentrate and the maximum Ti grade in the FeTi alloy was approximately $30 \mathrm{wt} \%$. Experimentally, it was verified that the FeTi alloy obtained under the optimum mixing conditions contained 30.2-30.8 wt \% Ti, 1.1-1.3 wt \% Si, 9.5-11.2 wt \% Al, and 56.9-58.0 wt \% Fe, along with trace impurities and small amounts of gases such as oxygen $(0.35-0.66 \mathrm{wt} \%)$ and nitrogen $(0.01-0.02 \mathrm{wt} \%)$. At the optimum mixing conditions, the recovery ratio of Ti into the obtained FeTi alloy phase was $60.6-68.9 \%$. These results matched closely with the thermodynamic calculations. Therefore, the thermodynamic calculations performed herein are expected to significantly contribute toward the development of new processes and improvement in conventional processes for producing various ferroalloys including the FeTi alloy through the aluminothermic process.
\end{abstract}

Keywords: aluminothermic process; recovery; ilmenite; ferrotitanium

\section{Introduction}

FeTi alloys are widely used in various industries such as steel, automotive, aerospace, and biomechanics. Generally, they are produced by the remelting process using Ti scrap as the raw Ti source [1-9]. However, the increasing price of Ti scrap and the instability in the supply of Ti scrap limit their applications. Furthermore, it is difficult to block oxygen and nitrogen during the remelting process [9]. Therefore, the aluminothermic process, which can produce FeTi alloy from cheap and abundant ilmenite $\left(\mathrm{FeTiO}_{3}\right)$ ore instead of Ti scrap [10-17], has attracted significant attention. This process is also industrially useful for producing ferroalloys such as ferrotungsten, ferromolybdenum, and ferrovanadium, which are used to improve the properties of cast iron and steel [18-20].

Generally, the aluminothermic process uses $\mathrm{Al}$ as the reducing agent; sodium chlorate $\left(\mathrm{NaClO}_{3}\right)$, potassium chlorate $\left(\mathrm{KClO}_{3}\right)$, sodium nitrate $\left(\mathrm{NaNO}_{3}\right)$, or potassium nitrate $\left(\mathrm{KNO}_{3}\right)$ as the exothermal agent; and calcium oxide $(\mathrm{CaO})$ or fluorspar $(\mathrm{CaF})$ as the slag-forming agent to produce the FeTi alloy from $\mathrm{FeTiO}_{3}$ concentrate $[2,21,22]$. In the process, vigorous heat is generated due to the chemical reaction between the charges, which is used to produce the FeTi alloy by the melting reduction of ilmenite $\left(\mathrm{FeTiO}_{3}\right)$; the production efficiency is significantly affected by the mixing ratio of the charges. Currently, a few studies have been conducted to determine the optimum production conditions. 
Chumarev et al. evaluated the production efficiency of the FeTi alloy according to the components of ilmenite $\left(\mathrm{FeTiO}_{3}\right)$ [2]. Misra et al. evaluated the recovery efficiency of Ti metals and the consumption of the reducing agent, $\mathrm{Al}$, according to the volume of slag used [23]. However, the thermodynamic calculation of optimum mixing conditions according to the amounts of the compounds used has not been investigated in detail.

Therefore, in this study, thermodynamic calculations were performed on the aluminothermic process for producing the $\mathrm{FeTi}$ alloy from ilmenite $\left(\mathrm{FeTiO}_{3}\right)$. Based on the calculated data, during the production of $\mathrm{FeTi}$ alloy from the $\mathrm{FeTiO}_{3}$ concentrate, the effects of the amounts of exothermal, slag-forming, and reducing agents (i.e., $\mathrm{NaClO}_{3}, \mathrm{CaO}$, and $\mathrm{Al}$, respectively) on the recovery of $\mathrm{Ti}$ were validated experimentally. We believe that the results obtained herein will provide a foundation for improving the conventional process or a developing new process to produce FeTi alloy from an $\mathrm{FeTiO}_{3}$ concentrate.

\section{Thermodynamic Calculation}

When the FeTi alloy is produced from the $\mathrm{FeTiO}_{3}$ concentrate using the aluminothermic process, the heat of the reaction is generated due to the chemical reaction between the charges. Therefore, the maximum temperature of the system in the reactor was obtained by analyzing the heat of reaction according to the mixing ratio of the charge materials. Additionally, the influence of changes in the amount of the reducing agent $(\mathrm{Al})$ and slag-forming agent $(\mathrm{CaO})$ on the composition of FeTi alloy and slag phases under equilibrium conditions was analyzed. These data are crucial for understanding the production process of the $\mathrm{FeTi}$ alloy from the $\mathrm{FeTiO}_{3}$ concentrate and improving the process technology. In this study, the equilibrium composition of the FeTi alloy and slag phases and the maximum temperature of the system were calculated based on the following assumptions:

(1) The $\mathrm{FeTiO}_{3}$ concentrate used in the thermodynamic calculation consists of $\mathrm{FeTiO}_{3}$ only without any impurities.

(2) The amount of $\mathrm{Al}$ required to reduce $100 \%$ of the $\mathrm{FeTiO}_{3}$ is one equivalent amount.

$$
\mathrm{FeTiO}_{3}+2 \mathrm{Al}=\mathrm{Fe}+\mathrm{Ti}+\mathrm{Al}_{2} \mathrm{O}_{3}
$$

(3) The recovery ratio of $\mathrm{Ti}$ and $\mathrm{Fe}$ in the FeTi alloy phase was $60 \%$ and $100 \%$, respectively, and the $\mathrm{Ti}$ in the slag was present in the form of TiO. This assumption was only utilized for calculating the maximum temperature of the system. Herein, the recovery ratios were selected based on the previously reported results [16,24].

(4) The mixing ratio of slag-forming agent $(\mathrm{CaO})$ was set to $30 \mathrm{wt} \%$ of $\mathrm{CaO}$ with a melting temperature of approximately $1730^{\circ} \mathrm{C}$ or lower based on the $\mathrm{Al}_{2} \mathrm{O}_{3}-\mathrm{CaO}$ binary slag system. This assumption was only utilized for calculating the maximum temperature of the system.

(5) The heat losses were $30 \%$ of the reaction heat in the system.

(6) The activity coefficient of all the compounds considered herein was one.

First, with regard to the variation in the amount of $\mathrm{Al}$ in the $\mathrm{FeTiO}_{3}, \mathrm{Al}$, and $\mathrm{CaO}$ system, the equilibrium composition was calculated using HSC Chemistry, Version 5.1, a chemical program developed by Outokumpu Research Oy. Table 1 lists the details of the chemical compounds considered in the calculation.

The amount of $\mathrm{Al}$ added was changed from one equivalent to one equivalent $+20 \%$. The mass balance and heat balance were calculated from the equilibrium composition. Based on these results, the maximum temperature generated by the charge reaction was calculated. Then, the maximum temperature of the system was calculated with the amount of $\mathrm{Al}$ in the $\mathrm{FeTiO}_{3}, \mathrm{Al}$, and $\mathrm{CaO}$ system and the amount of $\mathrm{NaClO}_{3}$ in the $\mathrm{FeTiO}_{3}, \mathrm{Al}, \mathrm{CaO}$, and $\mathrm{NaClO}_{3}$ system. 
Table 1. Chemical compounds considered for the thermodynamic calculation in the aluminothermic process.

\begin{tabular}{|c|c|c|c|c|}
\hline Gas & Chloride & Oxide & Oxide & Metal Phase \\
\hline $\mathrm{Al}(\mathrm{g})$ & $\mathrm{AlCl}_{3}$ & $\mathrm{Al}_{2} \mathrm{O}_{3}$ & $\mathrm{FeTi}_{2} \mathrm{O}_{5}$ & $\mathrm{Al}$ \\
\hline $\mathrm{AlCl}(\mathrm{g})$ & $\mathrm{Al}_{2} \mathrm{Cl}_{6}$ & $\mathrm{Al}_{2} \mathrm{O}_{3} \cdot \mathrm{TiO}_{2}$ & $\mathrm{Fe}_{2} \mathrm{TiO}_{4}$ & $\mathrm{Fe}$ \\
\hline $\mathrm{AlCl}_{2}(\mathrm{~g})$ & $\mathrm{AlClO}$ & $\mathrm{CaAl}_{2} \mathrm{O}_{4}$ & $\mathrm{NaFeO}_{2}$ & FeTi \\
\hline $\mathrm{Al}_{2} \mathrm{O}_{3}(\mathrm{~g})$ & $\mathrm{AlOCl}$ & $\mathrm{CaAl}_{12} \mathrm{O}_{19}$ & $\mathrm{Na}_{8} \mathrm{Fe}_{2} \mathrm{O}_{7}$ & $\mathrm{Fe}_{2} \mathrm{Ti}$ \\
\hline $\mathrm{CaAl}_{2} \mathrm{Cl}_{8}(\mathrm{~g})$ & $\mathrm{CaCl}_{2}$ & $\mathrm{Ca}_{2} \mathrm{Al}_{2} \mathrm{O}_{5}$ & $\mathrm{NaO}_{2}$ & $\mathrm{Na}$ \\
\hline $\mathrm{CaCl}(\mathrm{g})$ & $\mathrm{CaOCl}_{2}$ & $\mathrm{CaFe}_{3} \mathrm{O}_{5}$ & $\mathrm{Na}_{2} \mathrm{O}$ & $\mathrm{Ti}$ \\
\hline $\mathrm{CaCl}_{2}(\mathrm{~g})$ & $\mathrm{FeCl}_{2}$ & $\mathrm{CaFe}_{5} \mathrm{O}_{7}$ & $\mathrm{Na}_{2} \mathrm{O}_{2}$ & TiAl \\
\hline $\mathrm{CaO}(\mathrm{g})$ & $\mathrm{FeCl}_{3}$ & $\mathrm{CaO}$ & $\mathrm{Na}_{2} \mathrm{O} \cdot \mathrm{Al}_{2} \mathrm{O}_{3}$ & $\mathrm{TiAl}_{3}$ \\
\hline $\mathrm{Cl}(\mathrm{g})$ & $\mathrm{FeOCl}$ & $\mathrm{CaO} \cdot \mathrm{Al}_{2} \mathrm{O}_{3}$ & $\mathrm{Na}_{2} \mathrm{O} \cdot \mathrm{Fe}_{2} \mathrm{O}_{3}$ & - \\
\hline $\mathrm{Cl}_{2}(\mathrm{~g})$ & $\mathrm{NaAlCl}_{4}$ & $\mathrm{CaO} \cdot 2 \mathrm{Al}_{2} \mathrm{O}_{3}$ & $\mathrm{Na}_{2} \mathrm{O} \cdot \mathrm{TiO}_{2}$ & - \\
\hline $\mathrm{Fe}(\mathrm{g})$ & $\mathrm{Na}_{2} \mathrm{AlCl}_{6}$ & $\mathrm{CaO} \cdot 6 \mathrm{Al}_{2} \mathrm{O}_{3}$ & $\mathrm{Na}_{2} \mathrm{O} \cdot 2 \mathrm{TiO}_{2}$ & - \\
\hline $\mathrm{FeAlCl}_{6}(\mathrm{~g})$ & $\mathrm{Na}_{3} \mathrm{AlCl}_{6}$ & $2 \mathrm{CaO} \cdot \mathrm{Al}_{2} \mathrm{O}_{3}$ & $\mathrm{Na}_{2} \mathrm{O} \cdot 3 \mathrm{TiO}_{2}$ & - \\
\hline $\mathrm{FeCl}(\mathrm{g})$ & $\mathrm{NaCl}$ & $3 \mathrm{CaO} \cdot \mathrm{Al}_{2} \mathrm{O}_{3}$ & $4 \mathrm{Na}_{2} \mathrm{O} \cdot 5 \mathrm{TiO}_{2}$ & - \\
\hline $\mathrm{FeCl}_{2}(\mathrm{~g})$ & $\mathrm{NaClO}_{2}$ & $12 \mathrm{CaO} \cdot 7 \mathrm{Al}_{2} \mathrm{O}_{3}$ & $\mathrm{Na}_{2} \mathrm{Ti}_{6} \mathrm{O}_{13}$ & - \\
\hline $\mathrm{FeO}(\mathrm{g})$ & $\mathrm{NaClO}_{3}$ & $4 \mathrm{CaO} \cdot \mathrm{Al}_{2} \mathrm{O}_{3} \cdot \mathrm{Fe}_{2} \mathrm{O}_{3}$ & $\mathrm{TiO}$ & - \\
\hline $\mathrm{FeOCl}(\mathrm{g})$ & $\mathrm{NaClO}_{4}$ & $\mathrm{CaO} \cdot \mathrm{Fe}_{2} \mathrm{O}_{3}$ & $\mathrm{TiO}_{2}$ & - \\
\hline $\mathrm{NaCl}(\mathrm{g})$ & $\mathrm{TiCl}_{2}$ & $2 \mathrm{CaO} \cdot \mathrm{Fe}_{2} \mathrm{O}_{3}$ & $\mathrm{Ti}_{2} \mathrm{O}_{3}$ & - \\
\hline $\mathrm{Na}_{2} \mathrm{Cl}_{2}(\mathrm{~g})$ & $\mathrm{TiClO}$ & $\mathrm{CaO} \cdot \mathrm{TiO}_{2}$ & $\mathrm{Ti}_{3} \mathrm{O}_{2}$ & - \\
\hline $\mathrm{NaO}(\mathrm{g})$ & - & $3 \mathrm{CaO} \cdot 2 \mathrm{TiO}_{2}$ & $\mathrm{Ti}_{4} \mathrm{O}_{7}$ & - \\
\hline $\mathrm{Na}_{2} \mathrm{O}(\mathrm{g})$ & - & $4 \mathrm{CaO} \cdot 3 \mathrm{TiO}_{2}$ & $\mathrm{Ti}_{5} \mathrm{O}_{9}$ & - \\
\hline $\mathrm{Na}_{2} \mathrm{O}_{2}(\mathrm{~g})$ & - & $\mathrm{Ca}_{3} \mathrm{Ti}_{2} \mathrm{O}_{7}$ & $\mathrm{Ti}_{6} \mathrm{O}_{11}$ & - \\
\hline $\mathrm{O}_{2}(\mathrm{~g})$ & - & $\mathrm{FeAl}_{2} \mathrm{O}_{4}$ & $\mathrm{Ti}_{7} \mathrm{O}_{13}$ & - \\
\hline $\mathrm{Ti}(\mathrm{g})$ & - & $\mathrm{FeNaO}_{2}$ & $\mathrm{Ti}_{8} \mathrm{O}_{15}$ & - \\
\hline $\mathrm{TiCl}(\mathrm{g})$ & - & $\mathrm{FeO}$ & $\mathrm{Ti}_{9} \mathrm{O}_{17}$ & - \\
\hline $\mathrm{TiCl}_{2}(\mathrm{~g})$ & - & $\mathrm{Fe}_{2} \mathrm{O}_{3}$ & $\mathrm{Ti}_{10} \mathrm{O}_{19}$ & - \\
\hline $\mathrm{TiClO}(\mathrm{g})$ & - & $\mathrm{Fe}_{3} \mathrm{O}_{4}$ & $\mathrm{Ti}_{20} \mathrm{O}_{39}$ & - \\
\hline $\mathrm{TiCl}_{2} \mathrm{O}(\mathrm{g})$ & - & $\mathrm{FeO} \cdot \mathrm{TiO}_{2}$ & - & - \\
\hline $\mathrm{TiO}(\mathrm{g})$ & - & $2 \mathrm{FeO} \cdot \mathrm{TiO}_{2}$ & - & - \\
\hline $\mathrm{TiO}_{2}(\mathrm{~g})$ & - & $\mathrm{FeTiO}_{3}$ & - & - \\
\hline
\end{tabular}

Herein, the amount of $\mathrm{NaClO}_{3}$, as an exothermal agent, was calculated based on the $\mathrm{TiO}_{2}$ content contained in the $\mathrm{FeTiO}_{3}$. Figure 1 shows the change in maximum temperature with the amount of $\mathrm{Al}$ in the $\mathrm{FeTiO}_{3}, \mathrm{Al}$, and $\mathrm{CaO}$ system, whereas Figure 2 shows the change in maximum reaction temperature with the amount of $\mathrm{NaClO}_{3}$ in the $\mathrm{FeTiO}_{3}, \mathrm{Al}, \mathrm{CaO}$, and $\mathrm{NaClO}_{3}$ system. Figure 1 shows that the maximum temperature in the $\mathrm{FeTiO}_{3}, \mathrm{Al}$, and $\mathrm{CaO}$ system was lower than $1420^{\circ} \mathrm{C}$ regardless of the amount of $\mathrm{Al}$ when the exothermal agent $\left(\mathrm{NaClO}_{3}\right)$ was not added. However, in the $\mathrm{FeTiO}, 3, \mathrm{Al}, \mathrm{CaO}$, and $\mathrm{NaClO}_{3}$ system, when the amount of $\mathrm{Al}$ was one equivalent, as shown in Figure 2, the maximum temperature of the system was higher than $1750{ }^{\circ} \mathrm{C}$ for $\mathrm{NaClO}_{3}$ greater than $20 \mathrm{wt} \%$. In addition, it was confirmed that when the amount of $\mathrm{Al}$ added was one equivalent $+10 \%$, the amount of $\mathrm{NaClO}_{3}$ should be greater than $15 \mathrm{wt} \%$ to maintain the reaction temperature of over $1750{ }^{\circ} \mathrm{C}$. Furthermore, the calculations suggest that the maximum temperature of the system decreased with an increase in the amount of $\mathrm{Al}$. The results suggest that $\mathrm{NaClO}_{3}$ is essential for producing the FeTi alloy from the $\mathrm{FeTiO}_{3}$ concentrate utilizing the aluminothermic process. Therefore, the maximum temperature of the system calculated at certain conditions, as shown in Figure 2, was higher than the melting temperature of the slag composition of $\mathrm{Al}_{2} \mathrm{O}_{3} 70 \mathrm{wt} \%-\mathrm{CaO} 30 \mathrm{wt} \%$ considered in the thermodynamic calculation. The melting temperature of the considered slag was approximately $1730^{\circ} \mathrm{C}$, as shown in the phase diagram of the $\mathrm{Al}_{2} \mathrm{O}_{3}-\mathrm{CaO}$ binary slag system [25] (Figure 3). 


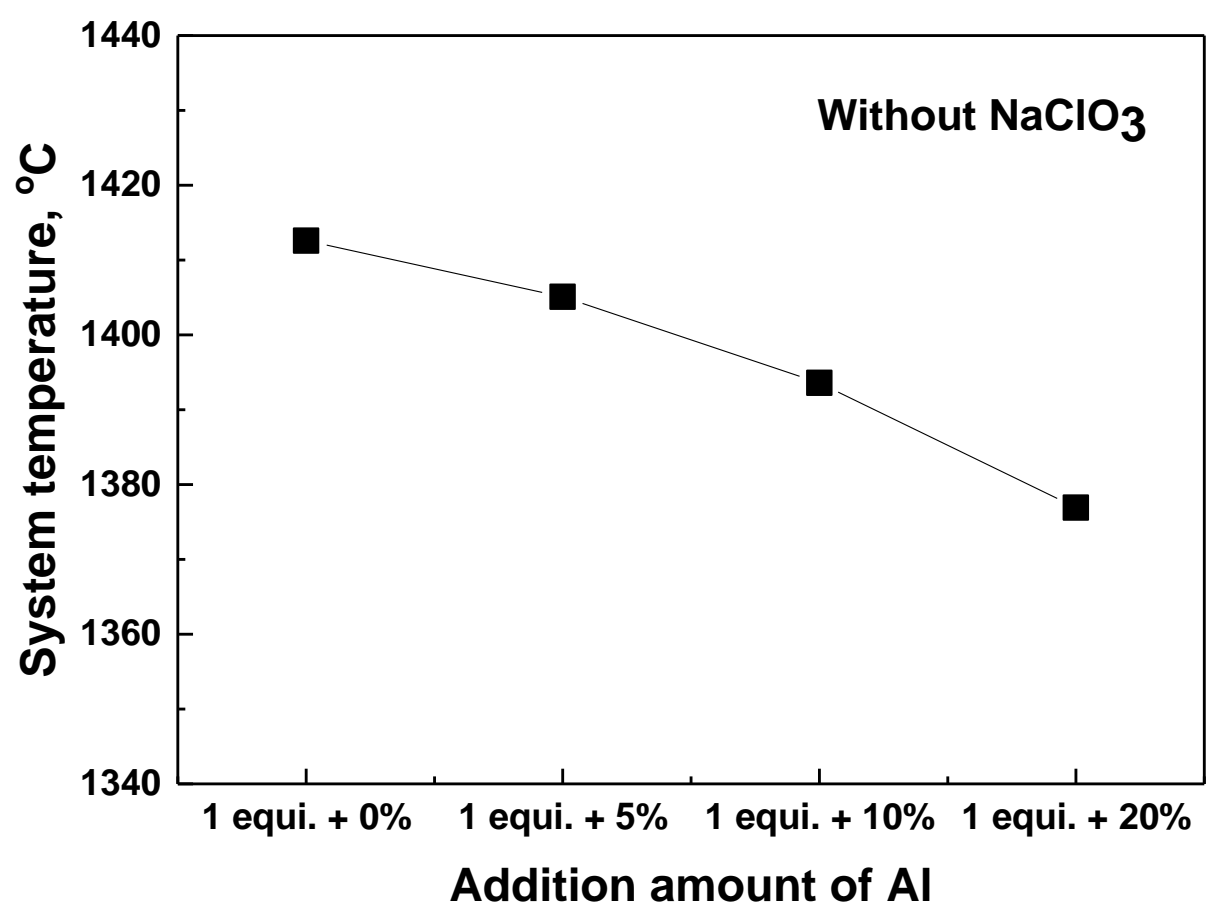

Figure 1. Maximum temperature of the aluminothermic process calculated according to the variation in the amount of $\mathrm{Al}$.

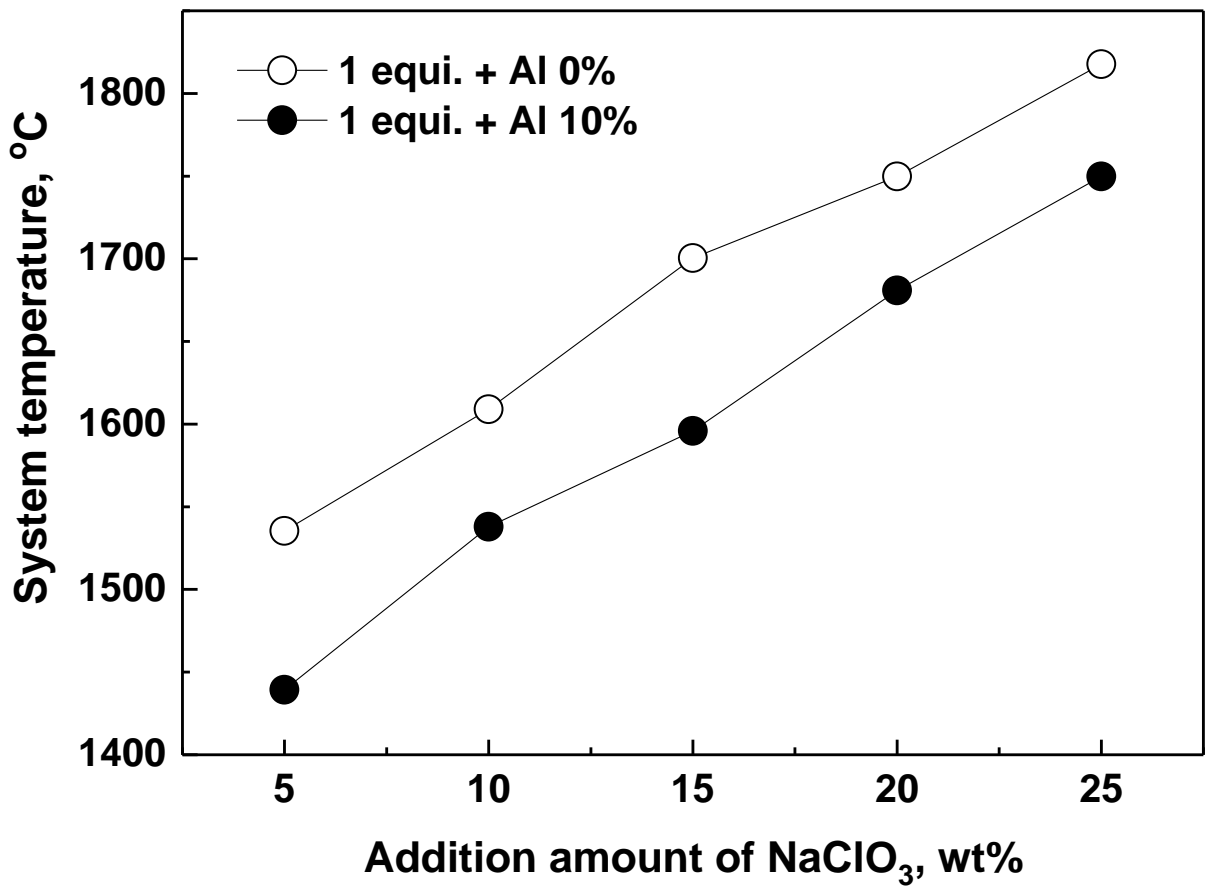

Figure 2. Maximum temperature of the aluminothermic process calculated according to the variation in the amount of $\mathrm{NaClO}_{3}$. 


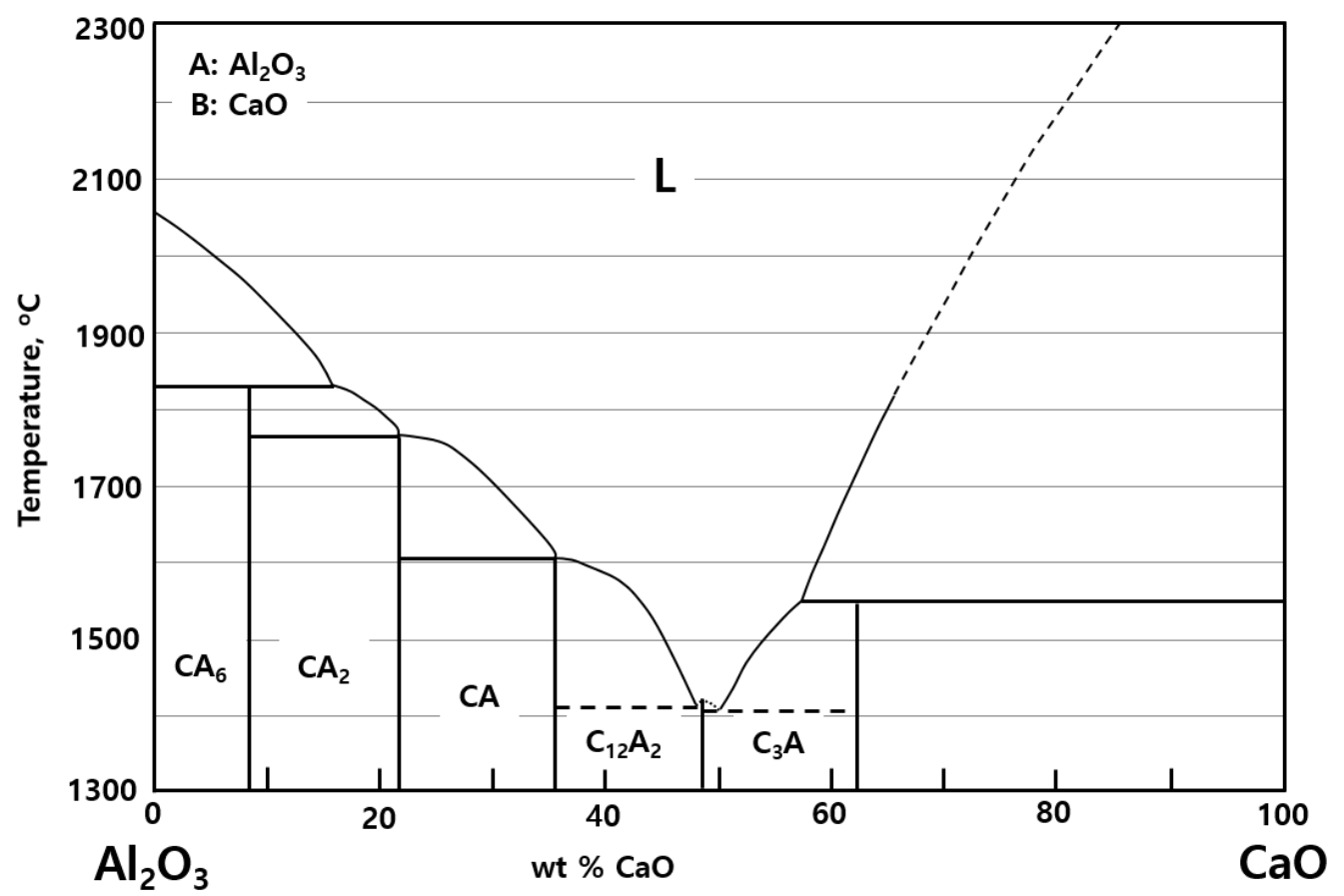

Figure 3. Phase diagram of the $\mathrm{Al}_{2} \mathrm{O}_{3}-\mathrm{CaO}_{2}$ binary slag system [10].

Next, based on the above-mentioned assumptions, the equilibrium composition was calculated using the chemical program HSC Chemistry, Version 5.1, for varying amounts of $\mathrm{Al}$ and $\mathrm{CaO}$ in the aluminothermic process wherein $\mathrm{FeTiO}_{3}, \mathrm{Al}, \mathrm{CaO}$, and $\mathrm{NaClO}_{3}$ were mixed. Table 1 lists the chemical compounds considered herein, and Figure 4 shows the metal grade of the FeTi alloy and the recovery ratio of $\mathrm{Ti}$ and $\mathrm{Fe}$ into the FeTi alloy phase according to the amount of $\mathrm{Al}$. The amount of $\mathrm{NaClO}_{3}$ was fixed at $20 \mathrm{wt} \%$ based on the weight of $\mathrm{TiO}_{2}$ in $\mathrm{FeTiO}_{3}$, whereas that of $\mathrm{CaO}$ was fixed at $7.5 \mathrm{wt} \%$ based on the weight of $\mathrm{FeTiO}_{3}$. As shown in Figure 4, the Ti grade in the FeTi alloy phase increased with the amount of $\mathrm{Al}$, and the Ti grade in the alloy phase was the highest (at approximately $30 \%$ ) in the vicinity of one equivalent of Al. However, the calculation results showed that when the amount of $\mathrm{Al}$ increased by more than one equivalent, the Ti grade in the alloy phase decreased gradually; this is because $\mathrm{Al}$, which does not participate in the reaction, melts into the FeTi alloy phase. Therefore, the Al content in the FeTi alloy phase increases with an increase in the amount of $\mathrm{Al}$, as shown in Figure 4 . Based on the results of the thermodynamic calculation, when an FeTi alloy containing less than $10 \mathrm{wt} \%$ of $\mathrm{Al}$ is produced using the aluminothermic process, the maximum Ti grade in the FeTi alloy is anticipated to be approximately $30 \mathrm{wt} \%$. However, the recovery ratio of Ti increases with an increase in the amount of $\mathrm{Al}$, and nearly all the $\mathrm{Fe}$ is recovered at $10 \mathrm{wt} \%$ or more of Al. Figure 5 shows the recovery ratio of $\mathrm{Ti}$ and $\mathrm{Fe}$ in the FeTi alloy phase and the amount of compound in the slag according to the amount of $\mathrm{CaO}$. Herein, the added amount of $\mathrm{NaClO}_{3}$ was fixed at $20 \mathrm{wt} \%$ based on the weight of $\mathrm{TiO}_{2}$ in $\mathrm{FeTiO}_{3}$, whereas that of $\mathrm{Al}$ was fixed at one equivalent. Figure 5 shows that when the amount of $\mathrm{CaO}$ is approximately $7.5 \mathrm{wt} \%$ compared to the charge amount of $\mathrm{FeTiO}_{3}$, the recovery ratio of $\mathrm{Ti}$ is the maximum in the FeTi alloy; however, the recovery ratio of Ti decreases as the amount of $\mathrm{CaO}$ increases over $7.5 \mathrm{wt} \%$. Furthermore, $\mathrm{TiO}$ and $\mathrm{CaO}^{*} \mathrm{TiO}_{2}$ contents in the slag phase gradually increase when the amount of $\mathrm{CaO}$ is over $7.5 \mathrm{wt} \%$. However, Fe does not appear to be significantly influenced by the amount of $\mathrm{CaO}$; therefore, when the $\mathrm{FeTi}$ alloy is produced from the $\mathrm{FeTiO}_{3}$ concentrate using the aluminothermic process, the amount of reducing agent, $\mathrm{Al}$, should be approximately one equivalent and that of the slag-forming agent, $\mathrm{CaO}$, should be approximately $7 \mathrm{wt} \%$ of the $\mathrm{FeTiO}_{3}$ concentrate. 


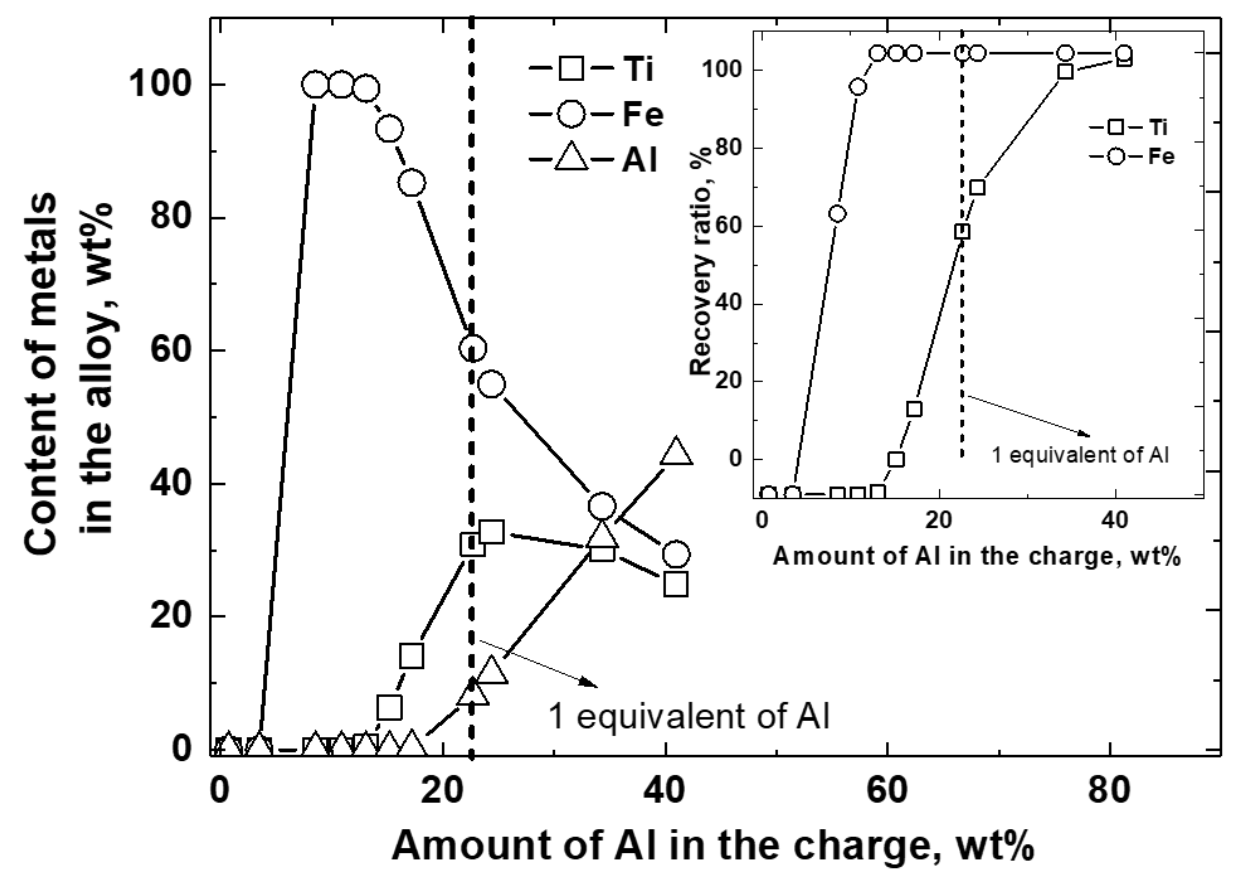

Figure 4. Metal grade in the FeTi alloy calculated according to the amount of $\mathrm{Al}$ (inset: recovery ratio of Ti and Fe calculated according to the amount of $\mathrm{Al}$ ).

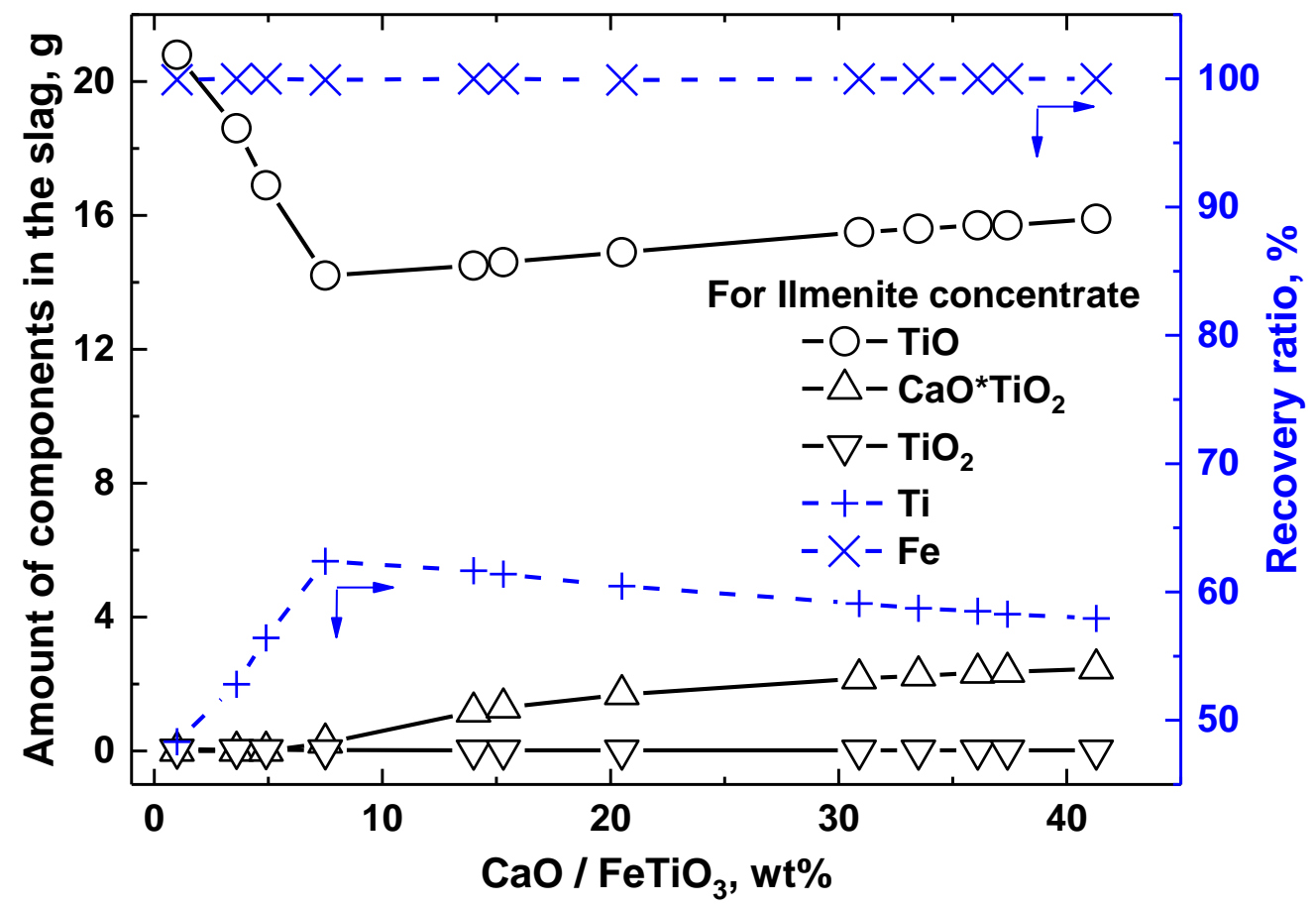

Figure 5. Amount of compound in the slag and recovery ratio of $\mathrm{Ti}$ and Fe calculated according to the amount of $\mathrm{CaO}$.

\section{Experimental Method}

The $\mathrm{FeTiO}_{3}$ concentrate was used as the raw Ti resource for producing the FeTi alloy, which was mined and sorted in a domestic $S$ mine company and had an average particle size of $59 \mu \mathrm{m}$ (Malvern Instruments, Malvern, UK, Malvern Instruments Mastersizer S3.01). Table 2 lists the chemical analysis values of the $\mathrm{FeTiO}_{3}$ concentrate used herein. $\mathrm{NaClO}_{3}$ powder of $98 \mathrm{wt} \%$ or more, produced by DUKSAN company in Korea, was utilized as the exothermal agent and was crushed to $3 \mathrm{~mm}$ or 
less (Malvern Instruments, Malvern, UK, Malvern Instruments Mastersizer S3.01). CaO powder of $96 \mathrm{wt} \%$ or more was utilized as the slag-forming agent, which was produced by the Samchun Chemical company in Korea. The Al metal powder, which acts as the reducing agent and heat source, was a recycled Al powder produced by the JMTECHKOREA company in Korea with an Al grade of $95 \mathrm{wt} \%$ or more and an average particle size of $1000 \mu \mathrm{m}$ (Malvern Instruments, Malvern, UK, Malvern Instruments Mastersizer S3.01). Figure 6 shows the x-ray diffraction pattern of the $\mathrm{FeTiO}_{3}$ concentrate used herein.

Table 2. Chemical analysis values of the $\mathrm{FeTiO}_{3}$ concentrate utilized in this study (wt \%).

\begin{tabular}{ccccccccc}
\hline $\mathrm{Al}_{2} \mathbf{O}_{3}$ & $\mathrm{CaO}$ & $\mathrm{MgO}$ & $\mathrm{MnO}$ & $\mathrm{Na}_{\mathbf{2}} \mathrm{O}$ & $\mathbf{P}_{2} \mathrm{O}_{5}$ & $\mathrm{FeTiO}_{3}$ & $\mathrm{Fe}_{2} \mathrm{O}_{3}$ & $\mathrm{SiO}_{2}$ \\
\hline 0.95 & 0.21 & 2.14 & 0.56 & 0.02 & 0.04 & 87.31 & 4.49 & 1.03 \\
\hline
\end{tabular}

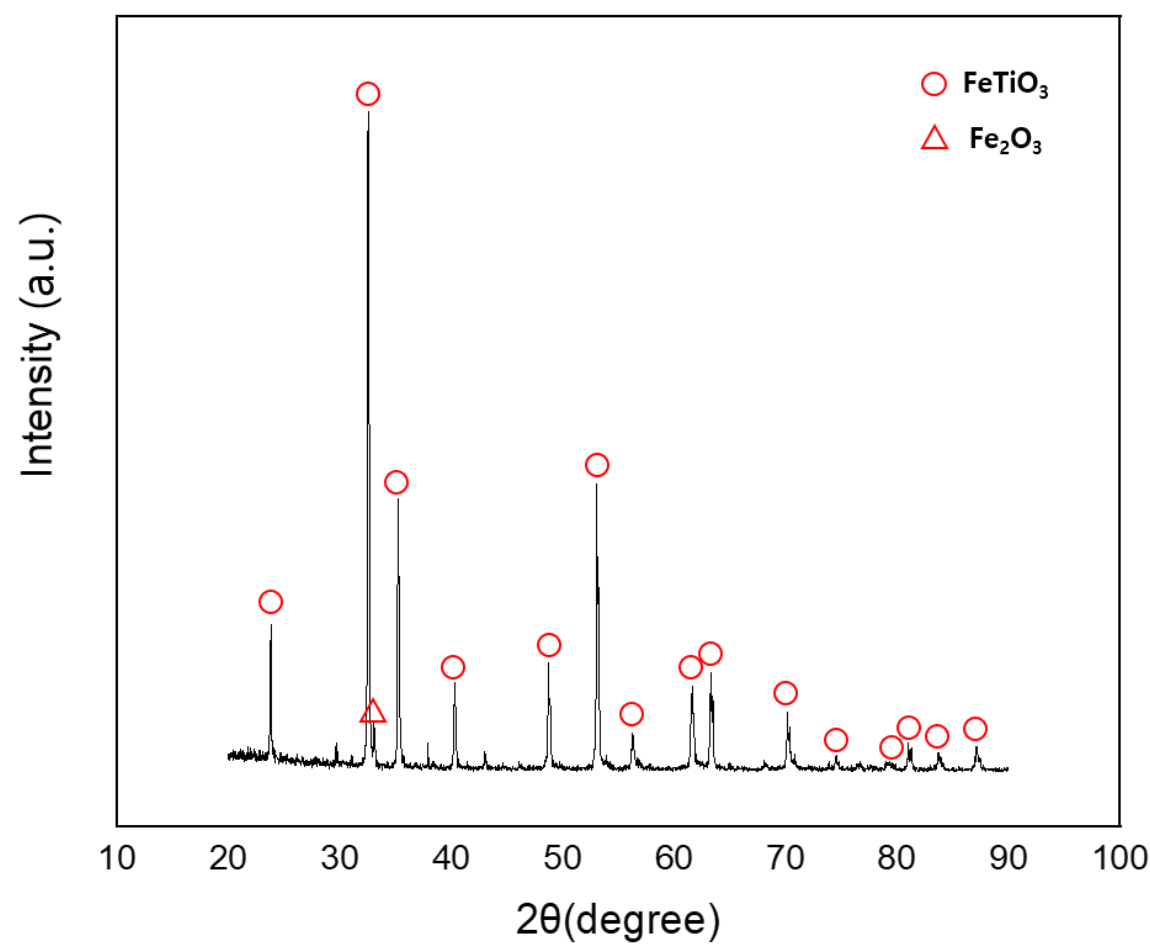

Figure 6. X-ray diffraction pattern of the $\mathrm{FeTiO}_{3}$ concentrate utilized in this study.

Figure 7 shows the aluminothermic reactor used herein, which consisted of a steel box with dimensions of $100 \mathrm{~cm} \times 80 \mathrm{~cm} \times 30 \mathrm{~cm}$ (width $\times$ length $\times$ height) filled with silica sand, and a space of $25 \mathrm{~cm} \times 25 \mathrm{~cm} \times 20 \mathrm{~cm}$ (width $\times$ length $\times$ height) was created using refractory bricks around the center of the steel box. In addition, a hood was attached to the top of the aluminothermic reactor. The sample was mixed for approximately 30 min using a sample mixer, as shown in Figure 8.

Under appropriate conditions, the experiment was conducted by mixing the $\mathrm{FeTiO}_{3}$ concentrate with the requisite amounts of recycled $\mathrm{Al}, \mathrm{CaO}$, and $\mathrm{NaClO}_{3}$, charging them in the aluminothermic reactor, and then igniting them with a magnesium ribbon. Meanwhile, in the preliminary experiment for producing the FeTi alloy under typical conditions without adding $\mathrm{NaClO}_{3}$ in the induction furnace, the FeTi alloy could not be produced. This is the reason why most of the reducing agent, Al powder, is consumed by reacting with oxygen in air during heating. Furthermore, the results obtained in the preliminary experiment, which investigated the variation in the Ti recovery ratio with the total charge amount in the aluminothermic reactor, suggested that the FeTi alloy had little impact on the Ti recovery at a total charge of $5 \mathrm{~kg}$ or more. Therefore, in all experiments, the total charge amount was fixed to approximately $6 \mathrm{~kg}( \pm 1.5 \%)$. 


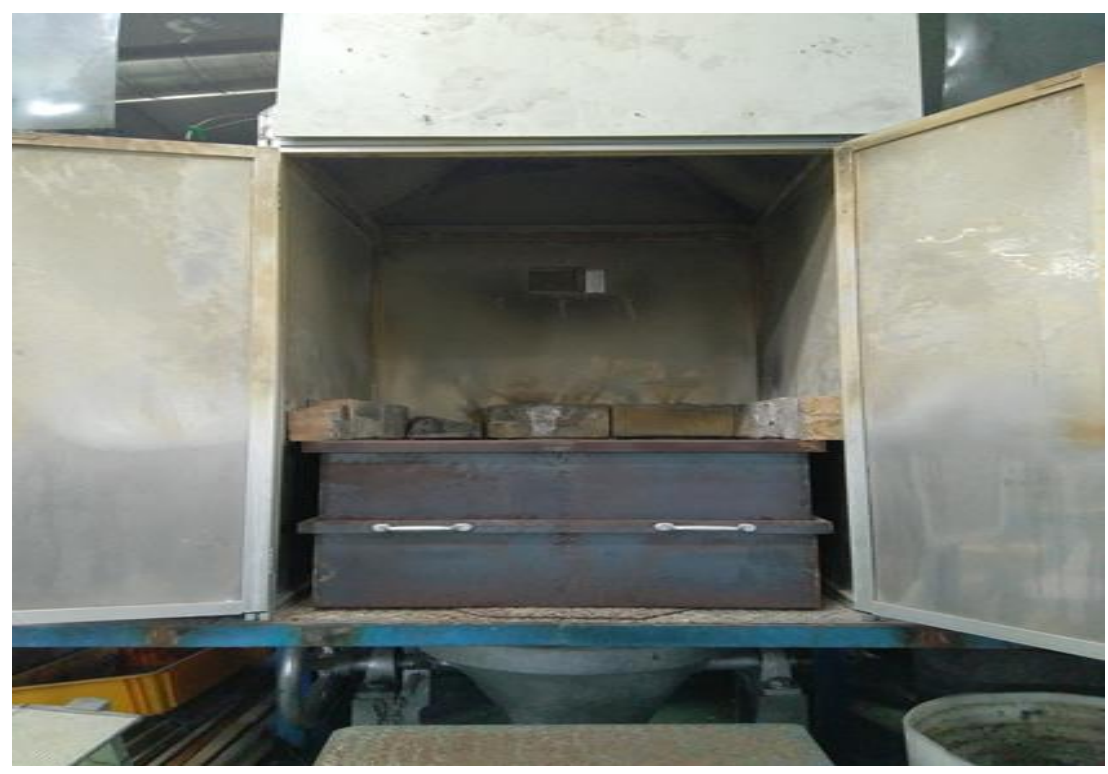

Figure 7. Photo of the aluminothermic reactor used in this study.

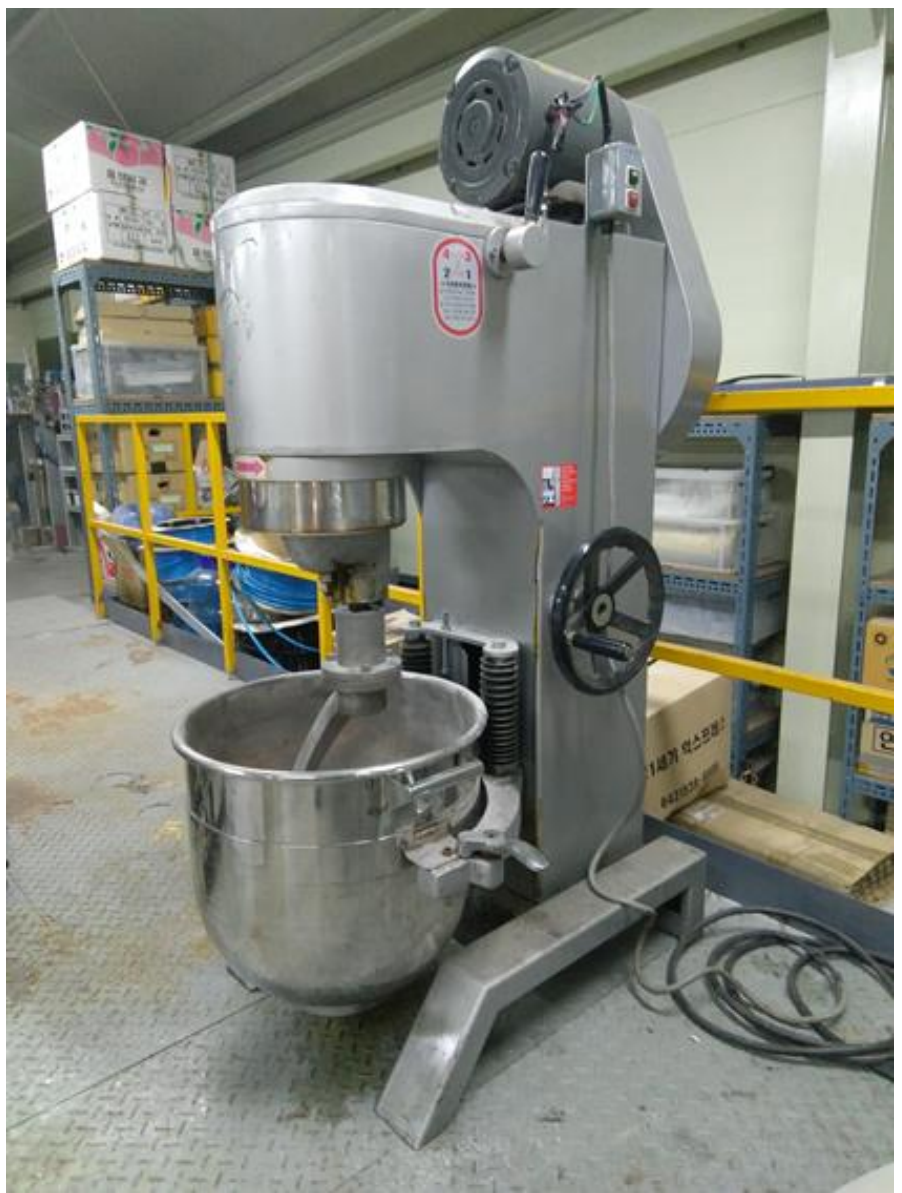

Figure 8. Photo of the sample mixer used in this study.

The FeTi alloy and slag recovered from the $\mathrm{FeTiO}_{3}$ concentrate were analyzed for Fe by a potassium dichromate titration method and for Si by the loss in weight on volatilization with hydrofluoric acid. The concentrations of $\mathrm{Al}$ and Ti were determined by inductively coupled plasma (ICP) spectroscopy (JY-38 plus, Horiba Ltd., Kyoto, Japan). The solution for the ICP analysis was prepared by decomposition with concentrated inorganic acids. The nitrogen and oxygen in the FeTi alloy recovered was also 
analyzed by ICP spectroscopy. The XRD patterns were obtained using an x-ray diffractometer (Rigaku D-max-2500PC, Rigaku/MSC, Inc., Woodlands, TX, USA) with $\mathrm{Cu}-\mathrm{K} \alpha$ radiation $(\lambda=0.154 \mathrm{~nm})$ operated at $40 \mathrm{kV}$ and $30 \mathrm{~mA}$. In addition, the recovery ratio of Ti and Fe recovered in the FeTi alloy phase was calculated as follows:

$$
\begin{aligned}
& \text { Ti recovery }(\%)=\frac{\text { Ti weight in FeTi alloy }(\mathrm{g})}{\text { Ti weight in slag }(\mathrm{g})+\text { Ti weight in FeTi alloy }(\mathrm{g})} \times 100 \\
& \text { Fe recovery }(\%)=\frac{\text { Fe weight in FeTi alloy }(\mathrm{g})}{\text { Fe weight in slag }(\mathrm{g})+\text { Fe weight in FeTi alloy }(\mathrm{g})} \times 100
\end{aligned}
$$

\section{Results and Discussion}

\subsection{Effect of the Exothermal Agent}

When the FeTi alloy was produced from the $\mathrm{FeTiO}_{3}$ concentrate using the aluminothermic process, we investigated the effect of the amount of $\mathrm{NaClO}_{3}$ on the recovery of Ti and Fe into the FeTi alloy phase by changing the amount of $\mathrm{NaClO}_{3}$ compared to the weight of $\mathrm{TiO}_{2}$ in the $\mathrm{FeTiO}_{3}$ concentrate from 0 to $25 \mathrm{wt} \%$. In this experiment, the slag-forming agent, $\mathrm{CaO}$, was added based on $30 \mathrm{wt} \%$ of $\mathrm{CaO}$ in the expected slag composition of the $\mathrm{Al}_{2} \mathrm{O}_{3}-\mathrm{CaO}$ binary slag system, and one equivalent of $\mathrm{Al}$ was added to the charge. Table 3 lists the charge amounts for each experiment, and Figure 9 shows the effects of adding an exothermal agent on the recovery of Ti and Fe in the FeTi alloy phase. This figure shows that the FeTi alloy cannot be produced from the $\mathrm{FeTiO}_{3}$ concentrate only by the heat generated due to the self-reaction between $\mathrm{Al}$ and the charge without the addition of $\mathrm{NaClO}_{3}$. However, it was confirmed that the recovery of $\mathrm{Ti}$ and Fe increased with an increase in the amount of $\mathrm{NaClO}_{3}$. Specifically, the recovery ratio of $\mathrm{Ti}$ was greater than $62 \%$, when 15 wt $\%$ or more of $\mathrm{NaClO}_{3}$ was added, suggesting that the recovery ratio does not change significantly; however, nearly all the Fe was recovered. Accordingly, we concluded that the addition of $\mathrm{NaClO}_{3}$ is appropriate due to heat loss when there is approximately $20 \mathrm{wt} \%$ of the $\mathrm{TiO}_{2}$ content in the charged $\mathrm{FeTiO}_{3}$ concentrate.

Table 3. Charge amount for producing the FeTi alloy from the $\mathrm{FeTiO}_{3}$ concentrate according to the

\begin{tabular}{|c|c|c|c|c|}
\hline $\begin{array}{l}\text { Sample } \\
\text { No. }\end{array}$ & $\mathrm{NaClO}_{3}(\mathrm{~g})$ & $\begin{array}{c}\mathrm{FeTiO}_{3} \\
\text { Concentrate (g) }\end{array}$ & Recycled Al (g) & $\mathrm{CaO}(\mathrm{g})$ \\
\hline 1 & - & 3770.5 & 1 equivalent $=1300.0$ & 929.5 \\
\hline 2 & $\begin{array}{l}10 \mathrm{wt} \% \text { relative to the } \mathrm{TiO}_{2} \\
\text { component in the charged } \mathrm{FeTiO}_{3} \\
\text { concentrate }=169.9\end{array}$ & 3565.8 & 1 equivalent $=1315.6$ & 948.8 \\
\hline 3 & $\begin{array}{l}15 \text { wt } \% \text { relative to the } \mathrm{TiO}_{2} \\
\text { component in the charged } \mathrm{FeTiO}_{3} \\
\text { concentrate }=248.1\end{array}$ & 3471.5 & 1 equivalent $=1322.7$ & 957.6 \\
\hline 4 & $\begin{array}{l}20 \mathrm{wt} \% \text { relative to the } \mathrm{TiO}_{2} \\
\text { component in the charged } \mathrm{FeTiO}_{3} \\
\text { concentrate }=322.3\end{array}$ & 3382.1 & 1 equivalent $=1329.5$ & 966.0 \\
\hline 5 & $\begin{array}{l}25 \mathrm{wt} \% \text { relative to the } \mathrm{TiO}_{2} \\
\text { component in the charged } \mathrm{FeTiO}_{3} \\
\text { concentrate }=392.8\end{array}$ & 3297.2 & 1 equivalent $=1336$ & 974.0 \\
\hline
\end{tabular}
amount of the exothermal agent $\left(\mathrm{NaClO}_{3}\right)$. 


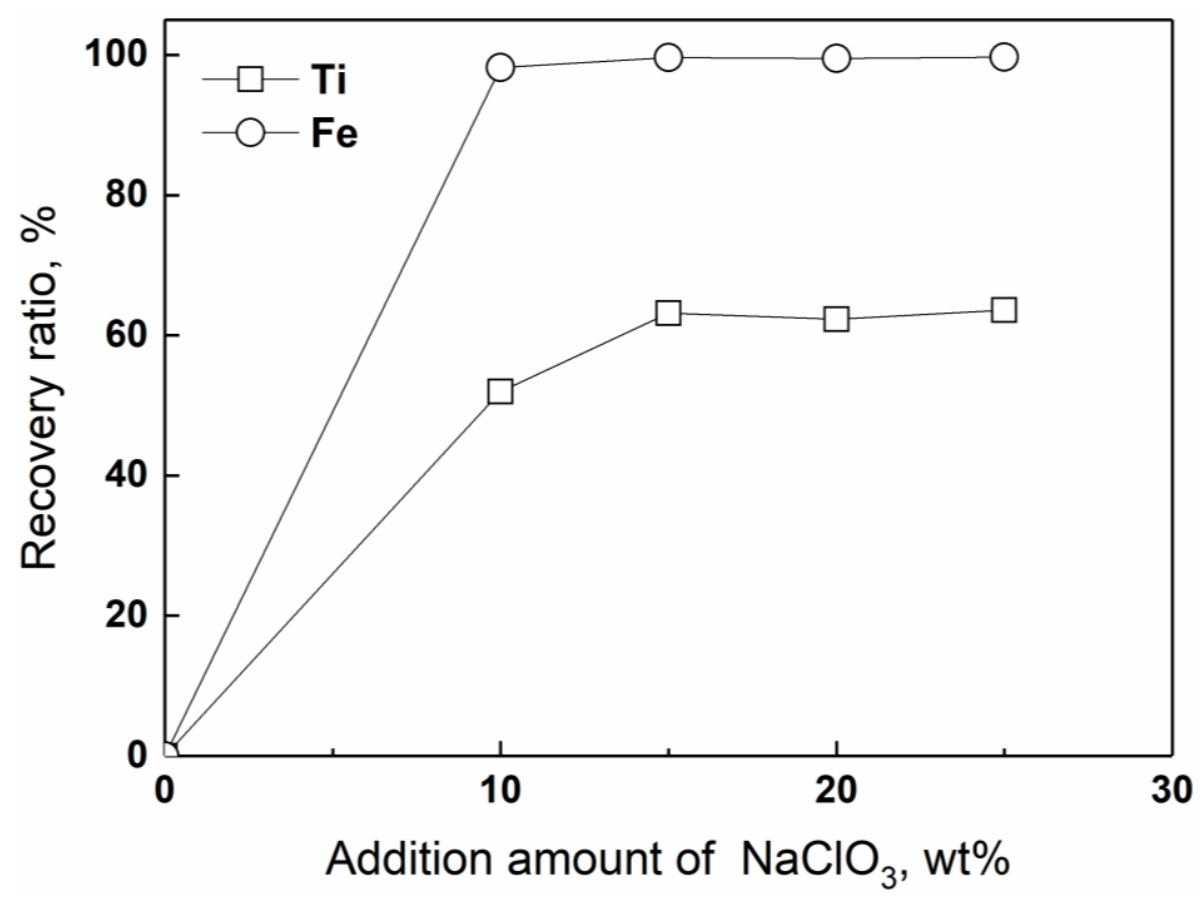

Figure 9. Recovery ratio of $\mathrm{Ti}$ and $\mathrm{Fe}$ according to the amount of $\mathrm{NaClO}_{3}$.

\subsection{Effect of the Slag-Forming Agent}

Table 4 shows the charge ratio used to investigate the effect of adding $\mathrm{CaO}$ on the recovery of $\mathrm{Ti}$ and $\mathrm{Fe}$ into the FeTi alloy phase. $\mathrm{CaO}$ was selected as the slag-forming agent since it has a higher affinity for oxygen than $\mathrm{Al}$ and forms a relatively low-temperature complex oxide. Thus, we investigated the recovery ratio of $\mathrm{Ti}$ and $\mathrm{Fe}$ in the FeTi alloy phase according to the amount of $\mathrm{CaO}$. In this experiment, the amount of $\mathrm{NaClO}_{3}$ was fixed as $20 \mathrm{wt} \%$ of the weight of $\mathrm{TiO}_{2}$ in the $\mathrm{FeTiO}_{3}$ concentrate, and one equivalent of $\mathrm{Al}$ was added to react with the oxides that could be reduced by $\mathrm{Al}$ in the charge. Figure 10 shows the recovery ratio of Ti and Fe in the FeTi alloy phase according to the amount of $\mathrm{CaO}$ added during the aluminothermic process. As shown in Figure 10, the recovery ratio of $\mathrm{Ti}$ and $\mathrm{Fe}$ was relatively constant from 7.2 to $28.6 \mathrm{wt} \%$ of the amount of $\mathrm{CaO}$, and then, the ratio decreased at $35.9 \mathrm{wt} \%$. This trend was slightly different from the theoretical calculation result in the previous section (Figure 5), which is possibly attributed to the impurities in the $\mathrm{FeTiO}_{3}$ concentrate, as shown in Table 2. Accordingly, in the aluminothermic process for producing thee FeTi alloy from the $\mathrm{FeTiO}_{3}$ concentrate, the appropriate amount of $\mathrm{CaO}$ to add was approximately $16.6 \mathrm{wt} \%$ of the amount of the $\mathrm{FeTiO}_{3}$ concentrate.

Table 4. Charge amount for investigating the effect of the addition of $\mathrm{CaO}$ on the recovery of Ti and Fe in the FeTi alloy phase.

\begin{tabular}{ccccc}
\hline Sample No. & $\mathrm{FeTiO}_{3}$ Concentrate $(\mathbf{g})$ & Recycled $\mathbf{A l}(\mathbf{g})$ & $\mathbf{C a O}(\mathbf{g})$ & $\mathbf{N a C l O}_{3}(\mathbf{g})$ \\
\hline 1 & 3844.1 & 1 equivalent $=1511.1$ & 278.4 & 366.3 \\
2 & 3627.3 & 1 equivalent $=1425.9$ & 601.1 & 345.7 \\
3 & 3508.6 & 1 equivalent $=1379.3$ & 777.8 & 334.4 \\
4 & 3382.1 & 1 equivalent $=1329.5$ & 966.0 & 322.3 \\
5 & 3247.0 & 1 equivalent $=1276.4$ & 1167.1 & 309.4 \\
\hline
\end{tabular}




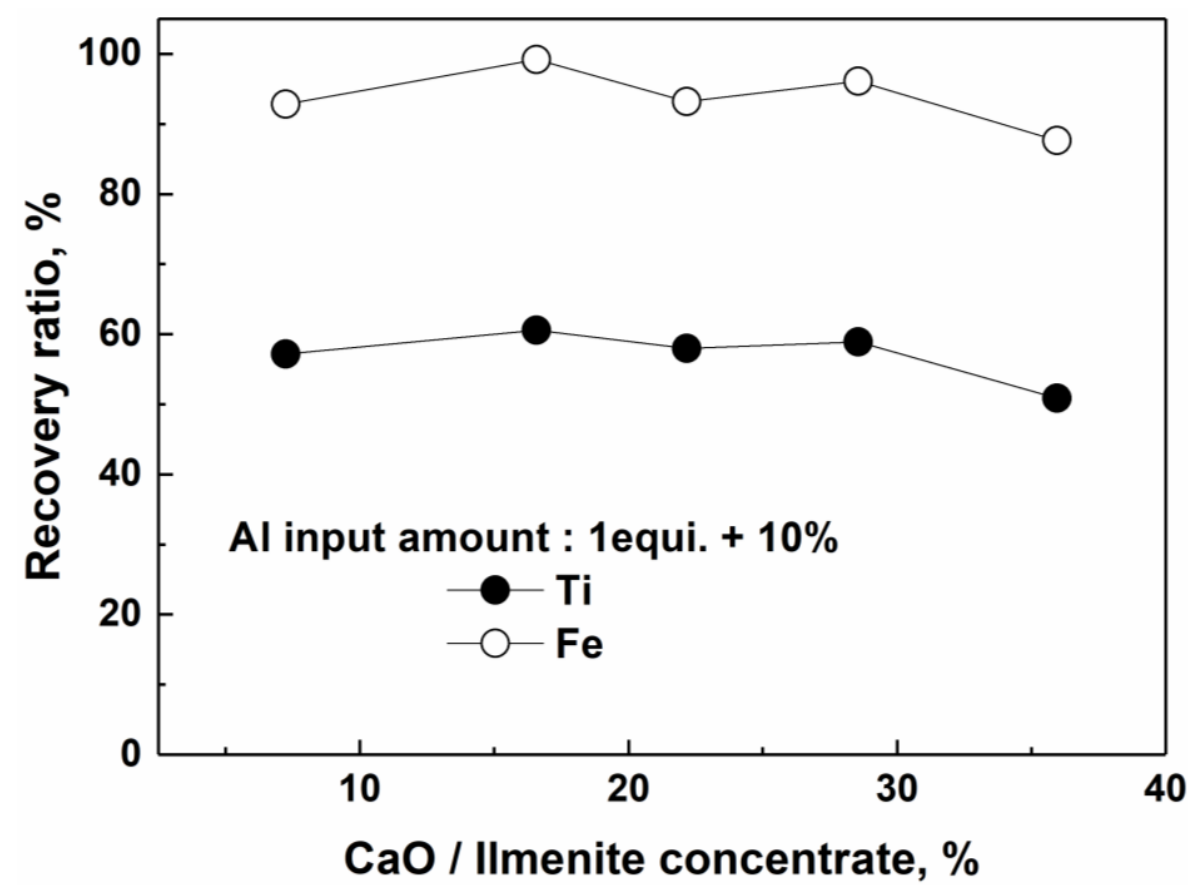

Figure 10. Recovery ratio of $\mathrm{Ti}$ and $\mathrm{Fe}$ according to the addition amount of $\mathrm{CaO}$.

\subsection{Effect of the Reducing Agent}

We investigated the effect of the amount of recycled $\mathrm{Al}$ on the production of the FeTi alloy from the $\mathrm{FeTiO}_{3}$ concentrate. In this experiment, the amount of $\mathrm{NaClO}_{3}$ was fixed as $20 \mathrm{wt} \%$ compared to the weight of $\mathrm{TiO}_{2}$ contained in the $\mathrm{FeTiO}_{3}$, and the amount of the $\mathrm{CaO}$ was fixed at $16.6 \mathrm{wt} \%$ compared to the charge amount of the $\mathrm{FeTiO}_{3}$ concentrate. The amount of recycled $\mathrm{Al}$ was changed from $23.8 \mathrm{wt} \%$ (one equivalent) to $24.8 \mathrm{wt} \%$ (one equivalent $+6 \%$ ) compared to the total charge amount. This is because the Ti grade in the FeTi alloy phase was the highest at approximately $30 \%$ in the vicinity of one equivalent of $\mathrm{Al}$, as obtained via the thermodynamic calculations (Figure 4). Figure 11 presents the experimental results for the amount of $\mathrm{Al}$ in the production process of the FeTi alloy from the $\mathrm{FeTiO}_{3}$ concentrate, which shows that the recovery ratio of Ti increased from $60.6 \%$ to $68.9 \%$ as the added amount of recycled $\mathrm{Al}$ increased. In addition, it was shown that the Ti grade in the FeTi alloy decreased slightly after $24 \mathrm{wt} \%$ of the amount of recycled Al. This indicates that the $\mathrm{Al}$ grade in the FeTi alloy increased as the added amount of recycled $\mathrm{Al}$ increased, which agreed with the above-mentioned thermodynamic calculation (Figure 4). As shown in Table 5, which presents the charge amount, the amount of the FeTi alloy, and chemical composition of the FeTi alloy, the FeTi alloy produced by varying the charge amount contained approximately $30.2-30.8 \mathrm{wt} \% \mathrm{Ti}, 1.1-1.3 \mathrm{wt} \%$ $\mathrm{Si}, 9.5-11.2 \mathrm{wt} \% \mathrm{Al}, 56.9-58.0 \mathrm{wt} \% \mathrm{Fe}$, and trace impurities. Utilizing a nitrogen/oxygen analyzer, the FeTi alloy was found to contain $0.35-0.66 \mathrm{wt} \%$ oxygen and $0.01-0.02 \mathrm{wt} \%$ nitrogen. The oxygen and nitrogen concentrations contained in the FeTi alloy were lower than those contained in the FeTi alloy produced from Ti scrap in a generally known atmosphere [25]. Figure 12 shows an image of the FeTi alloy obtained herein and the XRD pattern. The XRD analysis revealed that the FeTi alloy primarily contained $\mathrm{Fe}_{2} \mathrm{Ti}_{1} \mathrm{AlFe}_{3}$, and $\mathrm{Fe}$ phases. From the above experimental results, the optimum mixing conditions were found to be $\mathrm{NaClO}_{3}$ at $20 \mathrm{wt} \%$ relative to the weight of $\mathrm{TiO}_{2}$ contained in the $\mathrm{FeTiO}_{3}$ concentrate; recycled $\mathrm{Al}$ powder between $23.8 \mathrm{wt} \%$ (one equivalent) and $24.8 \mathrm{wt} \%$ (one equivalent $+6 \%$ ) relative to the total charge amount; and $\mathrm{CaO}$ at $16.6 \mathrm{wt} \%$ relative to the charge amount of the $\mathrm{FeTiO}_{3}$ concentrate. It was also confirmed that when the FeTi alloy containing less than $10 \mathrm{wt} \%$ of $\mathrm{Al}$ was produced from the $\mathrm{FeTiO}_{3}$ concentrate by the aluminothermic process, the Ti grade in the resulting FeTi alloy was approximately $30 \mathrm{wt} \%$. This agreed well with the results from the thermodynamic calculation. 


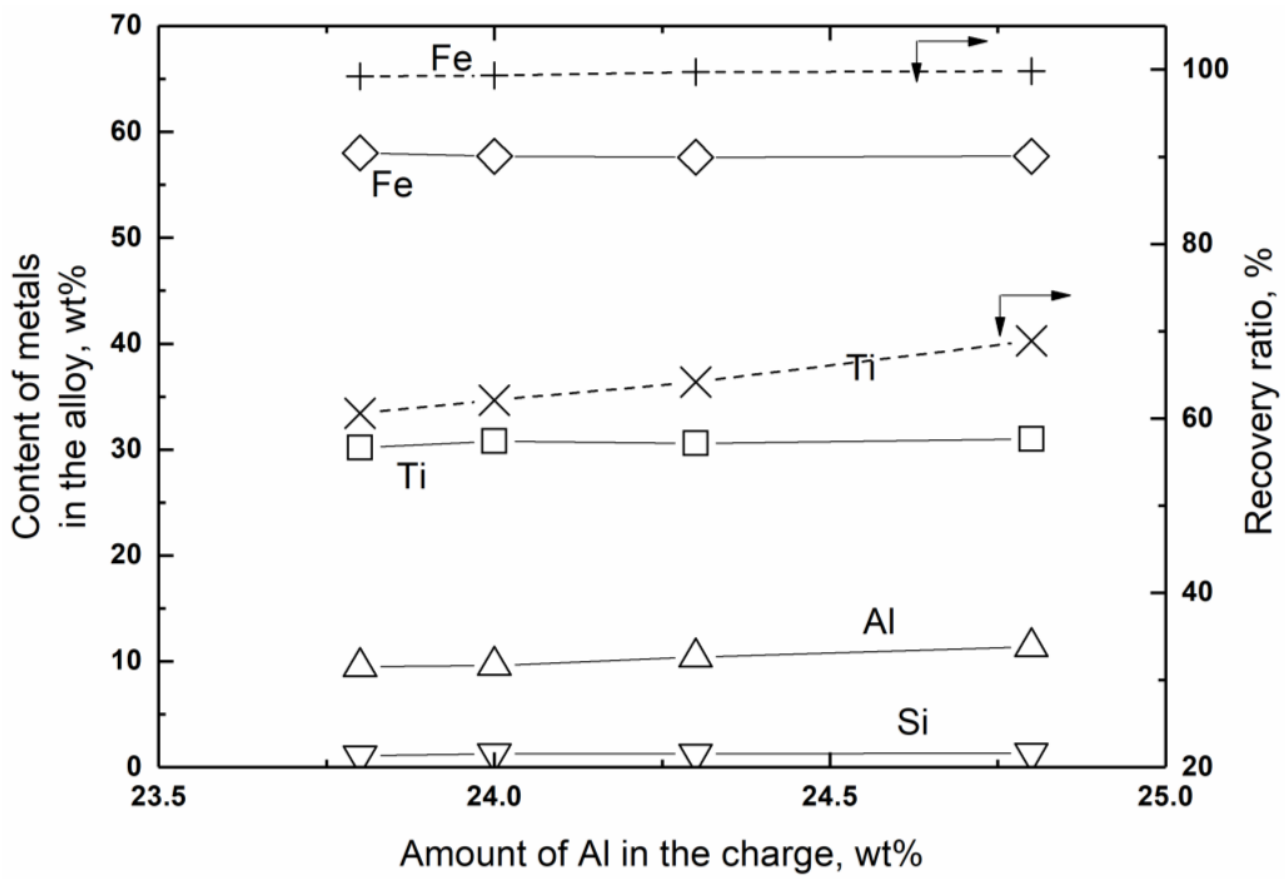

Figure 11. Effect of the added amount of recycled $\mathrm{Al}$ on the recovery of Ti and Fe in the FeTi alloy phase.

Table 5. Chemical composition and amount of FeTi alloy produced by varying the charge.

\begin{tabular}{|c|c|c|c|c|c|c|c|}
\hline \multirow{2}{*}{$\begin{array}{l}\text { Sample } \\
\text { No. }\end{array}$} & \multicolumn{4}{|c|}{$\begin{array}{c}\text { Composition of FeTi Alloy } \\
\text { Phase (wt \%) }\end{array}$} & \multicolumn{2}{|c|}{ Charge Amount } & \multirow{2}{*}{$\begin{array}{l}\text { Produced } \\
\text { Alloy } \\
\text { Weight }\end{array}$} \\
\hline & Ti & Al & $\mathrm{Fe}$ & Si & Recycled Al & $\begin{array}{c}\mathrm{FeTiO}_{3} \text { Concentrate/ } \\
\mathrm{CaO} / \mathrm{NaClO}_{3}\end{array}$ & \\
\hline 1 & 30.2 & 9.5 & 58.0 & 1.1 & $\begin{array}{c}23.8 \mathrm{wt} \% \text { relative to total } \\
\text { charge amount } \\
(1 \text { equivalent }+0 \%=1425.9 \mathrm{~g}) \\
24.0 \text { wt } \% \text { relative to total }\end{array}$ & $3627.3 \mathrm{~g} / 601.1 \mathrm{~g} / 345.7 \mathrm{~g}$ & $1917 \mathrm{~g}$ \\
\hline 2 & 30.8 & 9.6 & 57.7 & 1.3 & $\begin{array}{c}\text { charge amount } \\
\text { (1 equivalent }+1.5 \%=1447.3 \mathrm{~g})\end{array}$ & & $2001 \mathrm{~g}$ \\
\hline 3 & 30.6 & 10.4 & 57.6 & 1.3 & $\begin{array}{c}24.3 \text { wt } \% \text { relative to total } \\
\text { charge amount } \\
\text { (1 equivalent }+3 \%=1468.7 \mathrm{~g} \text { ) }\end{array}$ & & $2073 \mathrm{~g}$ \\
\hline 4 & 30.5 & 11.2 & 56.9 & 1.2 & $\begin{array}{c}24.8 \text { wt } \% \text { relative to total } \\
\text { charge amount } \\
\text { (1 equivalent }+6 \%=1511.5 \mathrm{~g} \text { ) }\end{array}$ & & $2191 \mathrm{~g}$ \\
\hline
\end{tabular}
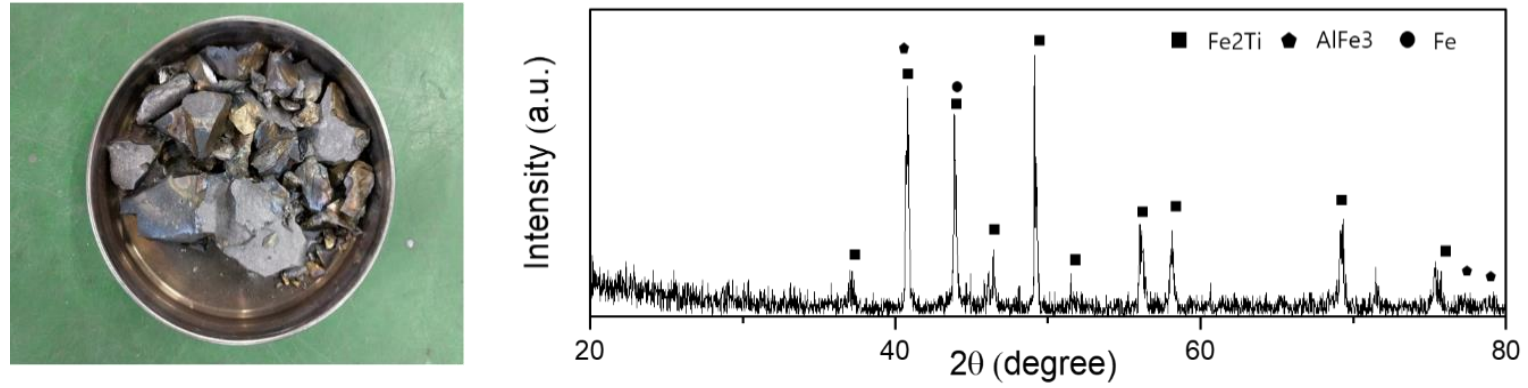

Figure 12. Photo and $x$-ray diffraction (XRD) pattern of the FeTi alloy produced from this study.

\section{Conclusions}

Herein, the aluminothermic process for producing the FeTi alloy from an $\mathrm{FeTiO}_{3}$ concentrate was investigated through thermodynamic calculation and validated experimentally. Through the theoretical thermodynamic calculations, the importance of an exothermal agent, $\mathrm{NaClO}_{3}$, in the production of FeTi 
alloy from an $\mathrm{FeTiO}_{3}$ concentrate was confirmed, and the optimum mixing conditions according to the amount of the compounds were predicted. From the thermodynamic calculations and experimental results, the optimum mixing conditions were:

- $\mathrm{NaClO}_{3}: 20 \mathrm{wt} \%$ relative to the weight of $\mathrm{TiO}_{2}$ contained in the $\mathrm{FeTiO}_{3}$ concentrate.

- $\quad$ Recycled Al powder: Between $23.8 \mathrm{wt} \%$ (one equivalent) and $24.8 \mathrm{wt} \%$ (one equivalent $+6 \%$ ) relative to the total charge amount.

- $\mathrm{CaO}: 16.6 \mathrm{wt} \%$ relative to the charge amount of the $\mathrm{FeTiO}_{3}$ concentrate.

The FeTi alloy produced in the optimum mixing conditions contained $30.2-30.8 \mathrm{wt} \% \mathrm{Ti}, 1.1-1.3 \mathrm{wt} \%$ $\mathrm{Si}, 9.5-11.2 \mathrm{wt} \% \mathrm{Al}$, and $56.9-58.0 \mathrm{wt} \% \mathrm{Fe}$. Under the same conditions, the recovery ratio of $\mathrm{Ti}$ in the FeTi alloy phase was $60.6-68.9 \%$, which agreed well with the thermodynamic calculations. The thermodynamic prediction performed herein is expected to contribute toward the development of new processes and the improvement of conventional processes for producing various alloys such as ferrotungsten, ferromolybdenum, and ferrovanadium including the FeTi alloy through the aluminothermic process. In addition, these results can provide a versatile approach to the scale-up strategy of the industrial aluminothermic process.

Author Contributions: Conceptualization, J.-H.C. and B.-S.K.; methodology, C.-W.N.; formal analysis, J.-H.C., H.C., T.R. and B.-S.K.; writing-original draft preparation, J.-H.C. and B.-S.K.; writing-review and editing, J.-H.C. and B.-S.K. All authors have read and agreed to the published version of the manuscript.

Funding: This research received no external funding.

Acknowledgments: This work was supported by the Basic Research Project (Grant Number: 20-3212-1) of the Korea Institute of Geoscience and Mineral Resources funded by the Ministry of Science and ICT of Korea.

Conflicts of Interest: The authors declare no conflict of interest.

\section{References}

1. Azizov, S.T.; Kachin, A.R.; Loryan, V.E.; Borovinskaya, I.P.; Mnatsakanyan, A.S. Aluminothermic SHS of ferrotitanium from ilmenite: Influence of $\mathrm{Al}$ and $\mathrm{KClO} 4$ content of green composition. Int. J. Self Propag. High Temp. Synth. 2014, 23, 161-164. [CrossRef]

2. Chumarev, V.M.; Dubrovskii, A.Y.; Pazdnikov, I.P.; Shurygin, Y.Y.; Sel'menskikh, N.I. Technological possibilities of manufacturing high-grade ferrotitanium from crude ore. Russ. Metall. 2009, 2008, 459-463. [CrossRef]

3. Zixian, G.; Gongjin, C.; He, Y.; Xiangxin, X.; Jongchol, R. Preparation of Ferrotitanium Using Ilmenite with Different Reduction Degrees. Metals 2019, 9, 662.

4. Qi, C.-C.; Hua, Y.-X.; Chen, K.-H.; Jie, Y.-F.; Zhou, Z.-R.; Ru, J.-J.; Xiong, L.; Gong, K. Preparation of ferrotitanium alloy from ilmenite by electrochemical reduction in chloride molten salts. JOM 2015, 68, 668-674. [CrossRef]

5. Pourabdoli, M.; Raygan, S.; Abdizadeh, H.; Hanaei, K. Production of high titania slag by Electro-Slag Crucible Melting (ESCM) process. Int. J. Miner. Process 2006, 78, 175-180. [CrossRef]

6. Pourabdoli, M.; Raygan, S.; Abdizadeh, H.; Hanaei, K. A new process for the production of ferrotitanium from titania slag. Can. Metall. Q. 2007, 46, 17-23. [CrossRef]

7. Kim, D.H.; Kim, T.S.; Heo, J.H.; Park, H.S.; Park, J.H. Influence of temperature on reaction mechanism of ilmenite ore smelting for titanium production. Metall. Mater. Trans. B 2019, 50, 1830-1840. [CrossRef]

8. Razavi, S.S.; Soltanieh, M. The investigation of the aluminothermic reduction of dissolved ilmenite in molten cryolite. Can. Metall. Q. 2015, 54, 460-466. [CrossRef]

9. Suzuki, K. An Introduction to the extraction, melting and casting technologies of titanium alloys. Met. Mater. Int. 2001, 7, 587-604. [CrossRef]

10. Panigrahi, M.; Shibata, E.; Iizuka, A.; Nakamura, T. Production of Fe-Ti alloy from mixed ilmenite and titanium dioxide by direct electrochemical reduction in molten calcium chloride. Electrochim. Acta 2013, 93, 143-151. [CrossRef]

11. Kang, J.; Moon, H.; Kim, M.-S.; Okabe, T.H. Production of High-grade Titanium Dioxide from Titanium Ore Using Titanium Scrap and Iron Chloride Waste. Met. Mater. Int. 2019, 25, 257-267. [CrossRef] 
12. Habashi, F. Handbook of Extractive Metallurgy; Wiley VCH Company: Weinheim, Germany, 1997; Volume 1, pp. 1129-1180.

13. Ray, H.S.; Sridhar, R.; Abraham, K.P. Extraction of Nonferrous Metals; Affiliated East-West Press: New Delhi, India, 1996; pp. 445-484.

14. Barbier, D.; Huang, M.; Bouaziz, O. A novel eutectic Fe-15 wt.\% Ti alloy with an ultrafine lamellar structure for high temperature applications. Intermetallics 2013, 35, 41-44. [CrossRef]

15. Kim, J.M.; Lee, H.W. Study for corrosion characteristics of ferritic stainless steel weld metal with respect to added contents of Ti and Nb. Met. Mater. Int. 2014, 20, 329-335. [CrossRef]

16. Sokolov, V.M.; Babyuk, V.D.; Zhydkov, Y.A.; Skok, Y.Y. Aluminothermic studies of a liquid partial reduced ilmenite. Miner. Eng. 2008, 21, 143-149. [CrossRef]

17. Yu, W.T.; Li, J.; Shi, C.-B.; Zhu, Q.-T. Effect of Titanium on the Microstructure and Mechanical Properties of High-Carbon Martensitic Stainless Steel 8Cr13MoV. Metals 2016, 6, 193. [CrossRef]

18. Ha, M.H.; (Woltech Korea Co., Ltd., Gyeongju, Gyeongsangbukdo, Korea). Private Communication. 2019.

19. Li, Z.N.; Wei, F.A.; La, P.Q.; Ma, F.L. Enhanced mechanical properties of 316L stainless steel prepared by aluminothermic reaction subjected to multiple warm rolling. Met. Mater. Int. 2018, 24, 633-643. [CrossRef]

20. Piao, R.; Yang, S.; Ma, L.; Wang, T. Vacuum Electromagnetic Levitation Melting of Ti-Al Based Alloy Prepared by Aluminothermic Reduction of Acid Soluble Ti Bearing Slag. Met. Mater. Int. 2020, 26, 130-142. [CrossRef]

21. Nersisyan, H.H.; Won, H.I.; Won, C.W. The laws of silicon ingot formation by combustion reaction. Met. Mater. Int. 2007, 13, 379-384. [CrossRef]

22. Maeda, M.; Yahata, T.; Mitugi, K.; Ikeda, T. Aluminothermic reduction of titanium oxide. Mater. Trans. JIM 1993, 34, 599-603. [CrossRef]

23. Misra, S.B.; Kamble, A.; Yadav, S.; Ranganathan, S. Influence of charge segregation on specific aluminium consumption in production of ferro-titanium. Can. Metall. Q. 2014, 54, 101-109. [CrossRef]

24. Babyuk, V.; Friedrich, B.; Sokolov, V. Investigations of Liquid Phase Aluminothermic Reduction of Ilmenite. World Metall. 2007, 60, 255-261.

25. Allibert, M.; Eisenhuttenleute, V.D. Slag Atlas, 2nd ed.; Verlag Stahleisen GmbH: Dusseldorf, Germany, 1995; p. 39.

Publisher's Note: MDPI stays neutral with regard to jurisdictional claims in published maps and institutional affiliations.

(C) 2020 by the authors. Licensee MDPI, Basel, Switzerland. This article is an open access article distributed under the terms and conditions of the Creative Commons Attribution (CC BY) license (http://creativecommons.org/licenses/by/4.0/). 